\title{
Current profile of Mansonella ozzardi (Nematoda: Onchocercidae) in communities along the Ituxi river, Lábrea municipality, Amazonas, Brazil
}

\author{
Jansen Fernandes Medeiros/ ${ }^{+}$, Victor Py-Daniel, Ulysses Carvalho Barbosa, \\ Guilherme Maerschner Ogawa
}

\author{
Laboratório de Etnoepidemiologia, Instituto Nacional de Pesquisas da Amazônia, Caixa Postal 478, 69011-970 Manaus, AM, Brasil
}

The objective of this paper was to describe the current status of Mansonella ozzardi prevalence among the inhabitants of 12 communities along the Ituxi river, in Lábrea municipality, state of Amazonas. The prevalence of M. ozzardi was determined using thick blood smears obtained by digital punctures. M. ozzardi was found in $30.23 \%$ of the samples collected (39/129), with similar prevalence between genders (males: 30.30\%; females: 30.16\%); the highest prevalence was found in homemakers (45.45\%) followed by farmers (38.77\%). Among age groups, males and females older than 48 exhibited the highest rates. These results show a significative increase in the prevalence when compared to a epidemiological study made 26 years ago in the same area as well as a different epidemiological profile (gender and occupation) in relation to other areas in Amazonas.

Key words: Filariasis - Mansonelliasis - Mansonella ozzardi

Mansonella ozzardi (Manson 1897) is one of the etiological agents of mansonelliasis. In Brazil, Deane (1949) registered the first occurrence of this filariasis in Manaus, state of Amazonas. Mansonelliasis is still a poorly studied filarial disease, with doubtful pathogeneticity. People with mansonelliasis and high microfilaremia present moderate fever, joint pain, adenitis, headache, and coldness in the legs (Batista et al. 1960b). The presence of ocular findings and possible corneal lesions has been linked to this filaria (Branco et al. 1998).

In the municipality of Lábrea, an endemic area of M. ozzardi, the first report of this filaria was made by Costa (1956) and Rachou (1957). Shelley (1975) studied the prevalence of M. ozzardi and Shelley and Shelley (1976) found black flies as vectors of M. ozzardi in this region. Tavares and Alecrim (1980) and Tavares (1981) made an epidemiologic study along the Ituxi River and observed that the prevalence increase after the second decade of life and that the majority of cases occurred in workers in contact with forest. In this municipality, specifically in communities along the Ituxi river, when filaria is found in the thick blood smears in individuals who present symptoms similar to those of malaria, patients are treated with ivermectin.

The aim of the present work is to update the epidemiological studies of this filarial disease among people living along the Ituxi river. The work was carried out in communities along this river in the municipality of Lábrea $\left(07^{\circ} 15^{\prime} \mathrm{S} 64^{\circ} 51^{\prime} \mathrm{W}\right)$, in the state of Amazonas, Brazil, in May 2007. The Ituxi river, a tributary of the Purus river (Fig.), has a total length of $640 \mathrm{~km}$, whose

Financial support: FAPEAM

+ Corresponding author: jmedeiro@inpa.gov.br

Received: 25 January 2008

Accepted: 10 June 2008 major tributaries are the Endimari, Curequetê, Ciriquiri and Arauã rivers. The population density is very low, and people live in small communities very dispersed along the river banks. The Ituxi river communities have been settled there for many years, keeping relatively isolated due to the long distance between the communities and the city of Lábrea (urban area). The population structure is the same of the above mentioned studies in that region. It has the same kind of houses, social behavior and occupation. Human population has diminished along the last 20 years after the end of the rubber exploration. We examined individuals from Ilha Verde, Cajajuriã, São Luis, Floresta, Volta do Bucho, Pedreira do Amazonas, Lago da Pedra, Palmapi, Cabeçudo, Bananal, Praia Alta e Capiruã communities, taking into account sex, age (2-9, 10-18, $19-27,28-37,38-47,48-57$, and $\geq 58$ years), and occupation (farmer, homemaker, student and teacher) following Tavares (1981). In this survey, at least $30 \%$ or more of the population of the largest communities were examined. We estimated the prevalence of $M$. ozzardi by examining two thick blood smears (about $0.02 \mathrm{ml}$ of blood each) obtained by digital punctures of each individual. After air-drying, the blood smears were dehemoglobinized in methylene blue, stained with Giemsa and microscopically examined (400x); when positive, the microfilariae (mf) were identified following WHO (1997) and Post et al. (2003). The present study was approved by the Ethics Committee of the Instituto Nacional de Pesquisas da Amazônia (protocol n. 043/2006). Informed verbal consent to participate in the study was obtained during meetings with the community elders and individual participants or in the case of children, their parents.

Of the 129 individuals examined, 39 (30.23\%) were M. ozzardi $\mathrm{mf}$ positive. The lowest prevalence (16.66\%) was found in Cajajuriã, and the highest (55.55\%) in Pedreira do Amazonas (Table I). The explanation for this may be related to spatial and temporal distribution of the vector larval breeding sites, and abundance of biting 


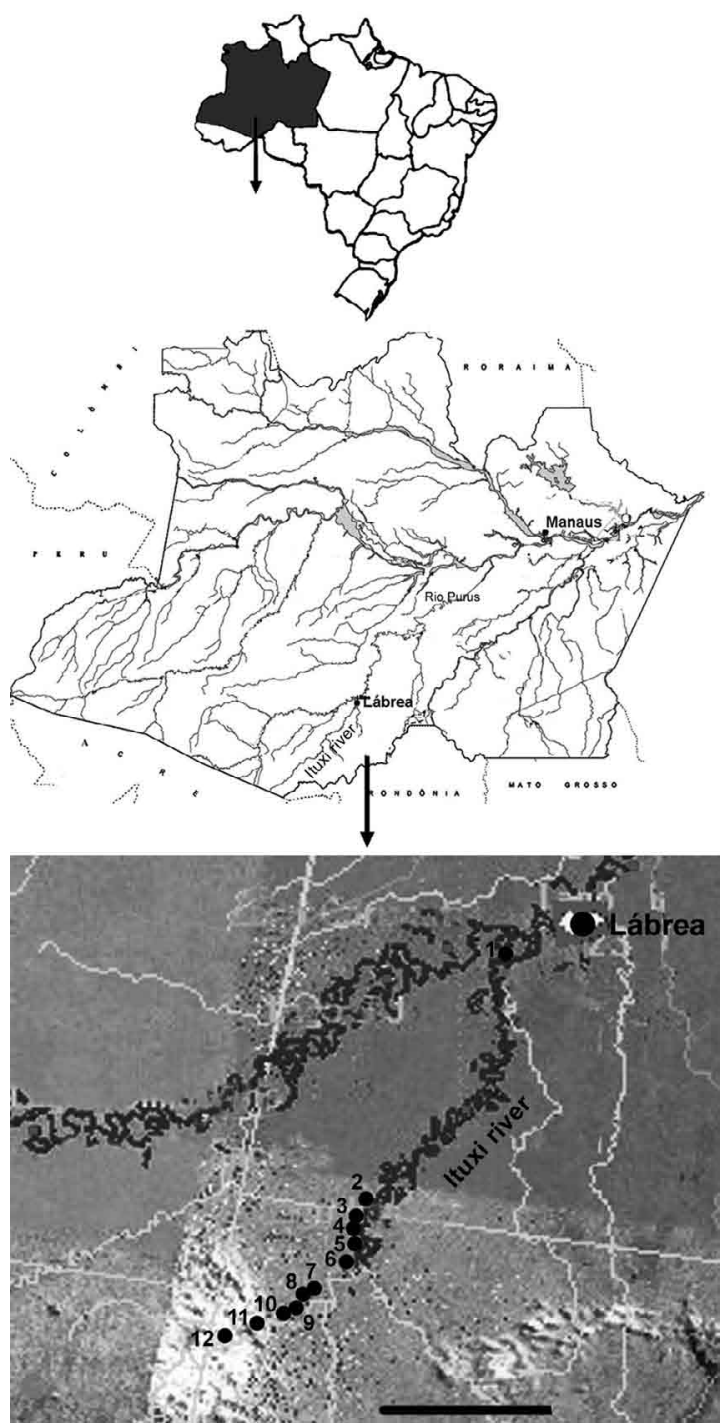

Location of the study area and communities along the Ituxi river, Lábrea municipality, Amazonas, Brazil. 1: Ilha Verde; 2: Cajajuriã; 3: Lago da Pedra; 4: São Luis; 5: Palmapi; 6: Cabeçudo; 7: Floresta; 8: Volta do Bucho; 9: Bananal; 10: Praia Alta; 11: Pedreira do Amazonas; 12: Capiruã.
Simuliid blackfly. The prevalence is high, especially when compared with the data of Tavares and Alecrim (1980) and Tavares (1981) (5.9\% and 4.7\%, respectively) for the Ituxi river, and of Shelley (1975) (4.4\%) for the Purus river communities, in Lábrea municipality. Of the 66 men and 63 women examined, $20(30.30 \%)$ and 19 (30.16\%) respectively were $M$. ozzardi $\mathrm{mf}$ positive. This similar prevalence between sexes in the Ituxi river is different from the epidemiological profile of mansonelliasis previously described in Amazonas, since males generally exhibited the highest prevalence (Batista et al. 1960a, Shelley 1975, Moraes et al. 1978, Tavares 1981). This unusual pattern found in the Ituxi river can be explained by the fact that males seek more frequently health services when they present malaria symptoms. When $\mathrm{mf}$ are occasionally found in blood smears during the malaria tests, people are sent off for treatment with ivermectin. We observed that males are more receptive to treatment than females (Table I), possibly because of ivermectin effects. Indeed, the local inhabitants and health professionals in the area report that the ingestion of the drug causes high fever, chills, nausea, general sickness, giddiness and rarely convulsion. These adverse reactions are caused by $\mathrm{mf}$ lysis after the ingestion of the drug. Among occupation categories, we verified that homemakers showed the highest prevalence (33 examined/15 positive; $45.45 \%$ ), followed by farmers (49 examined/19 positive: $38.77 \%$ ), students (44 examined/5 positive: $11.36 \%$ ) and teachers (3 examined/ 0 positive: $0 \%$ ). Usually farmers (males) showed the highest prevalence due to extensive daily activities in the field or along river margins, been more exposed to infective bites of simuliids. Batista et al. (1960a) and Shelley (1975) showed a higher prevalence in farmers $(69.7 \%$ and $16.7 \%$ respectively) and rubber collectors $(66.0 \%$ and 14.3\%). Tavares (1981) found a high prevalence in rubber collectors $(46.6 \%)$. Medeiros et al. (2007) found a higher prevalence in farmers $(47.37 \%)$, which might be directly related to the degree of exposure to vectors of M. ozzardi. The prevalence that increases with age is mentioned by various authors (Batista et al. 1960a, Moraes et al. 1978, Nathan et al. 1979, Tavares 1981, Medeiros et al. 2007).

\section{TABLE I}

Number of individuals examined/positive for Mansonella ozzardii in 12 Ituxi river communities, Lábrea municipality, Amazonas, Brazil, in May 2007

\begin{tabular}{|c|c|c|c|c|c|}
\hline \multirow[t]{2}{*}{ Communities } & \multicolumn{3}{|c|}{ Examined / Infected (Prevalence \%) } & \multicolumn{2}{|c|}{$\begin{array}{l}\text { Individuals treated with ivermectin } \\
\text { in the last three months, that } \\
\text { presented negative blood smears }\end{array}$} \\
\hline & Males & Females & Total & Males & Females \\
\hline Ilha Verde & $12 / 3(25.00)$ & $15 / 4(26.66)$ & $27 / 7(25.92)$ & 1 & 0 \\
\hline Cajajuriã & $3 / 1(33.00)$ & $3 / 0(0)$ & 6/1 (16.66) & 1 & 0 \\
\hline São Luis & $7 / 4(57.14)$ & $10 / 4(40.00)$ & $17 / 8(47.05)$ & 0 & 0 \\
\hline Floresta & $13 / 2(15.38)$ & $7 / 4(57.14)$ & $20 / 6(30.00)$ & 1 & 1 \\
\hline Volta do Bucho & $19 / 5(26.32)$ & $16 / 2(12.50)$ & $35 / 7(20.00)$ & 6 & 2 \\
\hline Pedreira do Amazonas & $4 / 1(25.00)$ & $5 / 4(80.00)$ & $9 / 5(55.55)$ & 0 & 0 \\
\hline Other $^{a}$ & $8 / 4(50.00)$ & $7 / 1(14.28)$ & $15 / 5(33.33)$ & 1 & 1 \\
\hline Total & $66 / 20(30.30)$ & $63 / 19(30.16)$ & $129 / 39(30.23)$ & 10 & 4 \\
\hline
\end{tabular}

a: total individuals examined from the communities of Lago da Pedra, Palmapi, Cabeçudo, Bananal, Praia Alta and Capiruã. 


\section{TABLE II}

Prevalence of Mansonella ozzardi by age and sex in 12 Ituxi river communities, Lábrea municipality, Amazonas, Brazil, in May 2007

\begin{tabular}{lrrr}
\hline & \multicolumn{3}{c}{ Examined/ Infected (Prevalence \%) } \\
\cline { 2 - 4 } Age group & \multicolumn{1}{c}{ Males } & \multicolumn{1}{c}{ Females } & \multicolumn{1}{c}{ Total } \\
\hline $2-9$ & $10 / 0(0)$ & $8 / 0(0)$ & $18 / 0(0)$ \\
$10-18$ & $10 / 1(10.00)$ & $19 / 5(26.31)$ & $29 / 6(20.69)$ \\
$19-27$ & $10 / 2(20.00)$ & $10 / 2(20.00)$ & $20 / 4(20.00)$ \\
$28-37$ & $14 / 5(35.71)$ & $15 / 5(33.33)$ & $29 / 10(34.48)$ \\
$38-47$ & $9 / 3(33.33)$ & $8 / 4(50.00)$ & $17 / 7(41.18)$ \\
$48-57$ & $4 / 3(75.00)$ & $1 / 1(100)$ & $5 / 4(80.00)$ \\
$\geq 58$ & $9 / 6(66.66)$ & $2 / 2(100)$ & $11 / 8(72.73)$ \\
\hline Total & $66 / 20(30.30)$ & $63 / 19(30.16)$ & $129 / 39(30.23)$ \\
\hline
\end{tabular}

We found the greatest rates among individuals older than 28 , with especially high prevalence in people over 48 (Table II).

As compared to Tavares (1981), who used the same diagnostic method, we found it likely that the prevalence increase in this region in the past 26 year is due to social and environmental factors, considering the lack of a continuous and wide-ranging treatment program to assist more people and not only restricted to those who seek treatment for malaria and/or mansonelliasis. We observed that some individuals that had been treated three months before our research had no mf (Table I); those individuals treated one year ago presented $\mathrm{mf}$ in their blood in our survey. Indeed, it is known that mf appear after 4-5 months of ivermectin treatment (Orihel et al. 1993).

\section{REFERENCES}

Batista D, Cerqueira NL, Moraes MAP 1960a. Epidemiologia da mansonelose em localidade do interior do Amazonas. Rev Ass Med Bras 6: 186-184.

Batista D, Oliveira WR, Rabello VD 1960b. Estudo da patogenicidade da Mansonella ozzardi e da sintomatologia da mansonelose. Rev Inst Med Tropical Sao Paulo 2: 281-289.
Branco BC, Chamon W, Belfort Neto R, Belfort Jr, Costa AJA 1998. Achados oculares entre habitantes do município de Pauini e possível associação entre lesões corneanas e mansonelose na Amazônia. Arq Bras Oftalmol 61: 674-682.

Costa OR 1956. Contribuição ao conhecimento de filariose na Amazônia. Rev Serv Esp Saúde Públ 8: 329-422.

Deane MP 1949. Sobre a incidência de filárias humanas em Manaus, Estado do Amazonas. Rev Serv Esp Saúde Públ 2: 849-858.

Medeiros JF, Py-Daniel V, Barbosa UC, Farias ES 2007. Epidemiological studies of Mansonella ozzardi (Nematoda, Onchocercidae) in indigenous communities of Pauini municipality, Amazonas, Brazil. Acta Amaz 37: 341-346.

Moraes MAP, Almeida MMR, Lovelace KJ, Chaves GM 1978. Mansonella ozzardi entre índios Ticunas do Estado do Amazonas, Brasil. Bol Oficina Sanit Panam 85: 16-25.

Nathan MB, Tikasingh ES, Nelson GS, Santiago A, Davies JB 1979. The prevalence and distribution of Mansonella ozzardi in coastal north Trinidad, W.I. Trans R Soc Trop Med Hyg 73: 299-302.

Orihel TC, Eberhard ML, Lowrie Jr RC 1993. Mansonella ozzardi: The course of patency in experimentally-infected patas monkeys. Trop Med Parasitol 44: 49-54.

Post RJ, Adams ZA, Shelley AJ, Maia-Herzog M, Luna Dias APA, Coscarón S 2003. The morphological discrimination of microfilariae of Onchocerca volvulus from Mansonella ozzardi. Parasitology 127: 21-27.

Rachou RG 1957. Distribuição geográfica das filarioses humanas no Brasil. Rev Bras Malariol Doenças Trop 9: 79-100.

Shelley AJ 1975. A preliminary survey of the prevalence of Mansonella ozzardi in some rural communities on the river Purus, state of Amazonas, Brazil. Ann Trop Med Parasitol 69: 407-412.

Shelley AJ, Shelley A 1976. Further evidence for the transmission of Mansonella ozzardi by Simulium amazonicum in Brazil. Ann Trop Med Parasitol 70: 213-217.

Tavares AM 1981. Estudo da infecção por Mansonella ozzardi. Universidade de Brasília, Brasília, 122 pp.

Tavares AM, Alecrim WD 1980. Filariose na área do rio Ituxi, Lábrea-AM. Mansonella ozzardi: Filtro de membrana e a epidemiologia da infecção. Rev Soc Bras Med Trop 16: 83.

WHO - World Health Organization 1997. Bench Aids for the Diagnosis of Filarial Infections, Geneva, $6 \mathrm{pp}$. 